набор бессвязных слов без всяких намеков на временную привязку. Очерк заканчивается словами: «Оба остались статьей очень довольны, и в ожидании звонка пристава отправили ее в типографию» [6.С. 5].

В одном из рассказов Дымов писал: «Жизнь жестоко и страшно шутит над нами» [10.С. 45]. Даровитый художник слова, мастер юмора и сатиры отвечал насмешливо и злобно времени, в котором ему довелось жить и творить. Личность этого журналиста-сатирика была довольно известной в России. Поэтому, когда он стал творить в духе импрессионизма и лирического пантеизма, одни критики отнеслись к его новой творческой вехе критически, другие, напротив, воспевали «очаровательную тонкость, чудесный лиризм, обаяние настоящего таланта и красоты» [3.С. 265]. Как разносторонняя личность Дымов умел совмещать труд журналиста и труд художника слова.

$$
* * *
$$

1. Бельская Э. Ежемесячный литературный журнал «Нева». 2002. № 11. С. 231-233.

2. Гамалова А. Вечный странник / Русский мир.ru. 2011. [Электронный pecypc]. URL: http://www.russkiymir.ru/media/magazines/article/100301

3. Гофман В. Осип Дымов. Веселая печаль. Критика и библиография / Новая жизнь. М.: Изд-во «Нов.журнала для всех». 1911. № 5. 276 С.

4. Дымов О. И. В кабинете Витте / Сигналы. Спб., 1906. Вып. 4. С. 5

5. Дымов О. И. Сатирикон. Издание М. Г. Корнфельда. Спб., 1911. 64 С.

6. Дымов О. И. Сигналы. Спб., 1906. Вып. 2. С. 5.

7. Дымов О. И. Хроника / Сигналы. Спб., 1906. Вып. 2. С. 3.

8. Дымов О. И. Я был лысым / Сигналы. Спб., 1905. Вып. 2. С. 7.

9. Первые литературные шаги. Автобиографии современных русских писателей / Собрал Ф. Ф. Фидлер. М.: Типография Т-ва И. Д. Сытина, 1911. 268 С.

10. Петровская Н. О творчестве Осипа Дымова. Перевал / Журнал свободной мысли. М.: Типография русского товарищества, 1907. №3. С. 45

11. Фредди Бен Натан. Дымова завеса: не знаменитая знаменитость [Электронный ресурс]. URL: http://kackad.com

12. Чуковский К. От Чехова до наших дней / Литературные портреты, характеристики. 3-е изд. исправленное и дополненное. СПб.и М.: Издание Т-ва М. О. Вольфь, 1908. 268 С.

\title{
Попова А.В.
}

\section{Типология героев в повестях А. Кима}

Волгоградский государственный технический университет (Россия, Волгоград)

doi:10.18411/lj-11-2018-106

idsp: ljournal-11-2018-106

\section{Аннотация}

В статье рассматриваются основные типы героев в повестях А. Кима, анализируются способы создания их образов, выявляются ключевые мотивы, роль персонажей в раскрытии авторского мировидения.

Ключевые слова: поэтика, повесть, тип героя, А. Ким.

А. Ким принадлежит к числу современных писателей, которые, вслед за величайшими русскими классиками, верят в высшую цель литературы преобразование человека и действительности, возможность духовного совершенствования человека. Поиски пути духовного развития человека, его восхождения к своему высшему осуществлению - вот то главное, что находится в центре авторского внимания, определяет поэтику, жанровое содержание его повестей.

Сквозь эту призму писатель отбирает жизненный материал, создает образы, выстраивает сюжет, композиционно соотносит фрагменты. Главные герои, духовный 
путь которых исследуется автором, обнаруживают удивительное сходство между собой. Можно выделить два основных типа героев в повестях А. Кима.

Первый представляет собой тип человека ищущего, сомневающегося, склонного к рефлексии, стремящегося понять истинный смысл человеческого пребывания на земле. Таким характерам свойственна склонность к грусти, печали и одиночеству, к каждому из них применимо известное есенинское «Грубым дается радость, нежным дается печаль». Обладая тонкой душевной организацией, эти герои оказываются в большей степени, чем другие, ранимы и уязвимы. У них развито чувство прекрасного, они восприимчивы к красоте окружающего мира, им доступны возвышенные наслаждения.

Определенная тенденциозность автора проявляется в том, что над вопросами экзистенциального характера в произведениях А. Кима задумываются не простые рабочие, но люди такого рода деятельности, как: магистр философии, учитель истории («Соловьиное эхо»), журналист («Нефритовый пояс»), актер («Утопия Гурина»), художник («Лотос»). Отметим, что фигура художника, творца в широком смысле этого слова вызывает особый интерес у А. Кима. Образы художников, живущих «детьми среди грубой свалки мира», впервые появляется в повести «Поклон одуванчику», затем будет в центре повести «Лотос», найдет свое дальнейшее выражение во всей полноте и многогранности в романе-сказке «Белка».

Можно выявить закономерности в способах создания образов главных героев. Лишая их ярко выраженных портретных, речевых характеристик, при очень малом количестве сведений биографического характера, писатель сосредотачивает все свое внимание на духовном облике, богатстве их внутренней жизни. Все временное, частное, индивидуально-конкретное отходит на второй план, на первый выступает обобщенный образ тревожного, вечно ищущего духа.

Внутреннее состояние главных героев А. Кима выражают сквозные мотивы тревоги, тоски, грусти и одиночества. При этом автор использует разнообразные эпитеты и сравнения, передающие оттенки этих чувств во всем их многообразии и глубине. Тревога «необъяснимая, смутная», «всеобъемлющая», «беспомощная», «неизбывная», «мучительная»; тоска «безутешная», «небывалая», «неосознанная», «сухая», «прожигающая насквозь сердце», «неимоверная, черная, как сама ночь, бесконечная», «тяжкая и грубая, как внезапное удушье»; одиночество «безграничное», «бескрайнее», «страшное».

Состояние тревоги, тоски и одиночества понимается писателем как свойство, присущее человеческому бытию в целом, а также характеризует умонастроение современного человека, живущего в век социально-политических, экологических катаклизмов и катастроф, становится неотъемлемым свойством бытия на рубеже XXXXI столетий.

С этими героями связан и один из центральных мотивов в творчестве писателя мотив духовной разобщенности людей. Причины трагической разъединенности, неспособности героев понять друг друга становятся предметом авторских раздумий в каждой повести.

Герою мятущемуся, дисгармоничному, противопоставлен в повестях А. Кима особый тип характера - «тип естественного человека». Он представлен в образах До Хок-ро и Масико («Собиратели трав»), старухи из «Лукового поля», старика-корейца Пака, матери Лохова («Лотос). Критики сразу отметили самобытность, неординарность этих характеров. Несмотря на странность, необычность этих персонажей, другую ментальность (все они - корейцы-переселенцы), каждый из них оказывается близок читателю каким-то глубинным, внутренним родством.

Хотя жизнь этих героев исполнена трагическими обстоятельствами, именно они являются наиболее гармоничными персонажами. Им не свойственны душевные метания и внутренний разлад, они не терзаемы сомнениями, отчаянием. Основу их 
характера составляет то же, что суть фольклорных персонажей, а именно: спокойное принятие своей доли, смиренное и безропотное перенесение тягот. Испытания, посылаемые героям судьбой, стойко переносятся ими, не вызывая при этом смены мировоззрения. С этим связана и некоторая «статичность» этих характеров.

Их главными качествами являются любовь и доброта. Именно материнская любовь помогла героине «Лотоса» преодолеть многочисленные испытания, она же дает ей силы в последние дни жизни на мгновение очнуться от забытья и услышать голос раскаивающегося сына. Через любовь чувствовала кровнородственную связь со всеми своими родными старуха из «Лукового поля».

Внутренняя сила, источник неоскудевающей жизненной энергии этих героев кроется в чувстве близости к природе, ощущении тесного родства с нею. Это выражено и в их образе жизни: довольствуясь малым, они берут на пропитание от самой земли. Природа же в повестях А. Кима предстает как единый, гармонично устроенный космос, в котором нет смерти, но есть бесконечное превращение вечно живой одухотворенной материи. Близость к природе, понимание себя как «простого сына земли, брата дереву и зверю» дарит человеку, согласно А. Киму, радостное бестревожное восприятие жизни. Таким образом, чувство взаимосвязанности со всем миром, ощущение себя частью целого, в одном ряду с травой, гусеницей, животным, является основой характера «естественного человека». Из ощущения тесного родства с природой следует восприятие смерти как явления естественного, означающего не конец бытия, но переход в иное бытие.

«Тип естественного человека» представляет собой наиболее цельный и гармоничный характер в системе персонажей писателя, воплощает философию всеединства, идею взаимосвязанности всего сущего, что составляет основу кимовского оптимизма.

1. Ким А. Соловьиное эхо. Рассказы. Повести. - М.: Советский писатель, 1980. - 608 с.

2. «От великой любви к Сахалину...»/ бес.ведет В. Семенчик // Литературная газета. - 2005. - № 39 40. - С. 7.

3. Смерть - всего лишь порог: А. Ким в беседе с обозревателем «Л.Г.» И. Кузнецовым// Литературная газета. - 1996. - № 6. - С. 5 .

\section{Романова М.А., Алешина О.И. \\ Словообразовательная специфика терминов фитнес - индустрии в современном английском языке}

Тульский государственный педагогический университет им. Л.Н. Толстого

(Россия, Тула)

doi:10.18411/lj-11-2018-107

idsp: ljournal-11-2018-107

\section{Аннотация}

В статье мы рассмотрим семантическую характеристику терминов сферы фитнеса и бодибилдинга в современном английском языке. Материалом исследования послужил журнал Джо Уайдера - Muscle\&Fitness («Масл энд фитнес», «Мышцы и фитнес»). В ходе исследования мы выявим основные виды терминов сферы фитнеса и бодибилдинга.

Ключевые слова: термин, термины - словосочетания, терминология, фитнес, фитнес - индустрия.

Развитие общества, науки и техники оказывает непосредственное влияние на качественный и количественный состав терминологических систем. Они постоянно 